\title{
Caro Pulido, Jessica (2020). Estrategias populistas en el discurso del M-19 en los medios gráficos a lo largo de su accionar guerrillero (1974-1990)
}

\author{
Jessica Lizeth Caro Pulido \\ jesikaro10@gmail.com \\ Universidad Nacional de La Plata, Argentina \\ Universidad Católica de Colombia, Colombia
}

Cita sugerida: Caro Pulido, J. L. (2021). [ Revisión de Tesis
Estrategias populistas en el discurso del M-19 en los medios gráficos
a lo largo de su accionar guerrillero (1974-1990)]. Aletheia,
12(23), e116. https://doi.org/10.24215/18533701e116

Defensa de Tesis: 29 de septiembre de 2020

Directora: Margarita Merbilhaá

El desarrollo de esta tesis se localiza dentro del campo de los estudios de la memoria y la historia a partir de la reconstrucción del contexto socio-histórico en el cual se desenvuelve el grupo guerrillero colombiano Movimiento 19 de abril (M-19), desde su surgimiento hasta su disolución (1974-1990), a la luz de la articulación entre las diversas estrategias de propaganda que desplegó en los medios de comunicación y el examen de un conjunto de tópicos que evidencian el carácter populista de su proyecto político. En efecto, es en el análisis de su estrategia populista donde esta tesis presenta una línea de análisis novedosa, pues no se reduce el fenómeno a la lucha armada, sino que se privilegia el estudio de sus estrategias de comunicación política, desentrañando los modos en que la organización buscaba generar consenso entre la población.

El objetivo principal de esta tesis apuntó a un análisis que fuera más allá de las interpretaciones que han predominado en los estudios sobre el M-19, centradas en el señalamiento de las contradicciones presentes tanto en su proyecto político-ideológico, como en la articulación entre su ideología y sus acciones. Y por 
tanto se propuso un análisis más riguroso de su propuesta política, que resultó un hito fundamental de la experiencia populista en Colombia cuyos orígenes se remontan a finales de la década del cuarenta.

El M-19 se insertó en el escenario político y social colombiano a partir de un evento sucedido a inicios de la década de los setenta, la sospecha de fraude en las elecciones presidenciales del 19 abril de 1970, que arrojaron como ganador un representante de los partidos políticos tradicionales en el país, y como perdedor al general Gustavo Rojas Pinilla, representante de una nueva propuesta política denominada Alianza Nacional Popular, ANAPO. Tomando como evento fundacional esta coyuntura, el M-19 configuró un marco político a su accionar armado, basado en un discurso de defensa de la democracia. Sin olvidar la lucha armada y la apuesta por la modernización del sistema democrático, que fue una de sus particularidades. Ello le permitió insertar en el espacio público un discurso con capacidad de agencia que innovó en el escenario de izquierda, desplazando sentidos preponderantes en base a luchas abiertas. Puesto que le permitió configurar una nueva visión de la guerrilla más receptiva a los ideales y afectos de sus integrantes. Esa heterogeneidad tan propia del M-19 tenía una gran capacidad contestataria y de interlocución que generó disputas y tensiones en los contextos en los cuales se desarrolló. Ello produjo múltiples rupturas en la escena política en general, en el sector de la oposición política al gobierno y en el terreno de las guerrillas.

Para abordar tanto las acciones realizadas por el M-19 a lo largo de casi dos décadas, así como su discurso e intervención en los medios de comunicación, esta tesis se estructuró en tres capítulos. En el primer capítulo se describió el marco histórico y político en el que surgió en Colombia un proceso populista, lo cual nos condujo a señalar tres elementos que el M-19 tomó de esa experiencia para la construcción de su discurso político: 1) La figura de Jaime Bateman; 2) su ideario en torno a la noción de democracia; y 3) la lógica de amigoenemigo. En el segundo capítulo presentamos las estrategias de comunicación del movimiento en torno a dos ejes: 1) la participación activa en publicaciones periódicas independientes como Mayorías y Alternativa; y 2) la irrupción en medios de comunicación tradicionales, como El Tiempo y El Espectador. Finalmente, en el tercer y último capítulo expusimos la manera en que el movimiento articuló su ideario político con las estrategias de comunicación mediante la escenificación de su discurso populista en el escenario público, a partir del análisis de determinados núcleos recurrentes en sus comunicados.

La delimitación del foco de análisis, que a su vez permitió la construcción del problema de investigación, se hizo con base a un recorte histórico en función de las principales acciones armadas del movimiento, así como de los principales acontecimientos históricos que utilizó el M-19 para dar legitimidad a su discurso. Pero principalmente se privilegió una sola interpretación de los hechos y de la realidad del país: la del M-19; dejando de lado múltiples experiencias revolucionarias, democráticas y contraculturales a lo largo de más de 40 años de historia.

Se privilegió esta versión porque ello nos permitió abordar una faceta hasta ahora poco estudiada del movimiento, su apuesta por la modernización del sistema democrático basados en novedosas estrategias de comunicación, mediante el análisis de las mediaciones existentes entre el proceso microsocial de emergencia y consolidación, y los contextos sociales y políticos que lo rodearon. Pues allí es donde puede rastrearse el origen del discurso populista del movimiento, ya que en su discurso se rememoran hechos del pasado para dar legitimidad a su discurso en el presente, a través de la integración de las clases populares en un esquema de articulación política multiclasista, con el objetivo de emerger en el espacio público como un interlocutor del discurso dominante, desde el cual se negaba el agotamiento de los partidos tradicionales y la falta de canales de participación al pueblo en su conjunto. 
Esta investigación tomó como principal fuente de análisis las fuentes documentales y periodísticas, que encontramos en comunicados, testimonios y artículos periodísticos generados a lo largo de 40 años de historia, ya que el interés se enfocó en los discursos del M-19, interpretando las connotaciones y resonancias en relación con tradiciones políticas previas ancladas en el imaginario popular.

La primera consulta realizada partió de una búsqueda de artículos periodísticos en la Hemeroteca de la Biblioteca Luis Ángel Arango (Bogotá, Colombia) que nos permitió reconstruir la relación establecida entre el M-19 y dos de los diarios más reconocidos y tradicionales del país para el periodo estudiado, El Tiempo y El Espectador. Así como la relación establecida con la revista de crítica política Alternativa.

Adicional a ello se emplearon como referencia los comunicados del M-19, que actualmente se encuentran digitalizados en la página virtual de CEDEMA (Centro de Documentación de los Movimientos Armados).

También fueron tomados como fuente los testimonios de ex militantes encontrados en libros que recopilan entrevistas realizadas durante los años setenta y ochenta a los militantes del M-19, como se puede ver en: Siembra vientosy recogerás tempestades, de Patricia Lara, cuya primera edición es de 1982, aunque la edición tomada es de 2014, actualizada con algunas otras entrevistas a los ex militantes del movimiento luego de la firma del acuerdo de paz en 1990. M-19: el heavy metal latinoamericano (1989), del periodista argentino Ángel Becassino, que estuvo en los campamentos del M-19, y habló con todos sus militantes. La espada de Bolivar (2006) de Jaime Jaramillo, recoge el testimonio vivo de José Yamel Riaño, uno de los fundadores del M-19. Y Colectivo Juvenil Carlos Pizarro, un colectivo que se dedicó a recoger entrevistas, noticias de prensa, testimonios relacionados con Jaime Bateman, unificándolos en documentos que ahora reposan como parte de la información del M-19 que reposa en CEDEMA.

El tratamiento dado a estas entrevistas y testimonios tuvo como objetivo la presentación del discurso de los militantes del M-19, apartándonos de una cierta retórica "enjuiciadora" de la historia, que aspira a establecer balances, aciertos y errores, sin la necesaria distancia crítica. Pues esta voz ha sido predominante por una parte de los discursos públicos, y allí radica nuestra intención en centrar la mirada en los aspectos políticos del M-19, que acompañaron sus acciones armadas.

Finalmente, del análisis de las estrategias de comunicación del movimiento, se identificó que aquello que otros autores han interpretado como contradicciones al interior del discurso del M-19 son elementos propios de la puesta en escena de su discurso populista, el cual buscaba la integración de las clases populares en un esquema de articulación política multiclasista, para emerger en el espacio público como un interlocutor del discurso dominante, desde el cual se negaba el agotamiento de los partidos tradicionales y la falta de canales de participación al pueblo en su conjunto. De allí que sus propuestas resultaran vagas, porque no se trataba tanto de proponer una solución pragmática como de señalar acciones que a su vez obedecieran a valores definidos aparte. Sus propuestas negaban la dimensión temporal a largo plazo porque buscaban reivindicaciones en el ahora, sin mediar las consecuencias que esto pudiera llegar a tener o si efectivamente pudiesen implicar la solución a la demanda que las originaba. 